\title{
IDENTIFIKASI RAYAP PERUSAK POHON DI ARBORETUM SYLVA UNIVERSITAS TANJUNGPURA
}

\author{
(Identification of Termits Which Attack Tree on Arboretum of Forestry Faculty Tanjungpura \\ University)
}

\author{
Sulantika dan Farah Diba \\ Fakultas Kehutanan Universitas Tanjungpura, Jalan Imam Bonjol Pontianak 78124 \\ Email : sulantikaulan@yahoo.co.id
}

\begin{abstract}
The main destructive wood organism is termites. Trees are attacked by live tree termites and also dead trees. As happened in the Arboretum area of Untan, where many trees were damaged caused by it. The aim of the study was to identify the types of tree destroyers in the Sylva Arboretum area of Untan. This study uses a field survey by exploring all the blocks found in the Untara Sylva Arboretum with an area of $3.2 \mathrm{ha}$. The results of the study at the Sylva University Arboretum in Tanjungpura from 20 observation blocks were 13 blocks which were attacked and 7 blocks were not exposed to termite attacks. Termites found 3 types of termites, these types include 2 types of soil termites (Nasutitermes Sp and Odontotermes Sp.) And 1 type of subterranean termites (Coptotermes curvignatus). The trees that were attacked in the Untan Arboretum area included 13 species of trees, namely: Acacia mangium, Acacia auriculiformis, Melicope lunu-acenda, Paraserianthes falcataria, Shorea seminis, Shorea pacipila, Shorea sp. Shorea revoluta, Dillenia sp, Gluta renghas, Calophillum inopilum, Nephelium lappaceum, Macarangga pruinosa. The most affected trees are Acacia mangium and Acacia Auriculiformis.
\end{abstract}

Keywords: Tree destroyer termites, Arboretum area

\section{PENDAHULUAN}

Arboretum pada umumnya ialah merupakan suatu kawasan kebun koleksi pepohonan dengan luasan tertentu berisi berbagai jenis pohon yang ditanam sedapat mungkin mengikuti habitat aslinya dan dimaksudkan sebagai areal pelestarian keanekaragaman hayati dan sedikitnya dapat memperbaiki atau menjaga kondisi iklim disekitarnya. ( Jom Faperta, 2015 ) Arboretum Sylva Untan berada ditengah Kota Pontianak Kalimantan Barat tepatnya di lingkungan Universitas Tanjungpura (Untan). Secara Geografis Arboretum Sylva Untan terletak diantara garis 623 21 Ls - 1092107 BT. Topografi yang relatif lebih datar dengan altiltude 0-1 dpl. Struktur geologi Arboretum berdasarkan peta geologi mempunyai skala 1 : 2000.000 terdiri dari batuan kuarter sedangkan tanahnya adalah aluvial. Arboretum Sylva Untan merupakan kawasan pelestarian plasma nutfah Kalimantan Barat, yang bertujuan sebagai tempat pengembangan pendidikan, pengembangan hutan kota serta sarana rekreasi dan hiburan bagi masyarakat.

Arboretum memiliki luas 3,2 hektar lahan dengan koleksi jenis tumbuhan, diantaranya merupakan jenis-jenis pohon dari hutan-hutan di Kalimantan Barat seperti Meranti, Ulin, Ramin, Jelutung, Gaharu, Bengkirai, Agathis, 
Macarangga pruinosa dll. Jenis pohon yang paling dominan di kawasan Arboretum Macarangga pruinosa dan Acacia. ( Sumber Marcel Garensa ) Kawasan Arboretum Sylva Untan memiliki keanekaragaman jenis pohon yang cukup tinggi dengan jumlah 20 blok, namun pada pohon di Arboretum juga banyak mengalami kerusakan. Salah satu penyebab dari kerusakan pada pohon di Arboretum ialah disebabkan oleh rayap. Pohon-pohon yang diserang rayap di Arboretum Sylva Untan ialah seperti pohon Acacia mangium, Acacia auriculiformis, Melicope lunu-acenda, Paraserianthes falcataria, Shorea seminis, Shorea pacipila, Shorea sp, Shorea revoluta, Macarangga pruinosa, Nephelium lappaceum, Calophillum inopilum, Gluta renghas, dan Dillenia. Tujuan dari penelitian ialah untuk mengidentifikasi jenis rayap perusak pohon di Kawasan Arboretum Sylva Universitas Tanjungpura.

\section{METODE PENELITIAN}

Penelitian dilaksanakan di Arboretum Sylva Universitas Tanjungpura Pontianak tanggal 5 agustus 2017 sampai 26 agustus 2017. Objek penelitian ini adalah pohon yang terserang rayap dan jenis rayap yang menyerang di Kawasan Arboretum Sylva Untan. Penelitian dilaksanakan dengan metode survey lapangan. Penentuan lokasi penelitian dibagi menjadi 20 blok, semua jenis pohon dalam blok diamati dan dicatat jenis pohon yang terserang rayap. Sampel rayap yang di ambil pada semua pohon yang terserang dimasukkan kedalam vial dan yang berisi alkohol selanjutnya diidentifikasi.

\section{HASIL DAN PEMBAHASAN}

Hasil penelitian di Arboretum Sylva Universitas Tanjungpura Pontianak, menjelaskan ada 13 blok yang terkena serangan rayap yang ditemukan 3 jenis rayap, jenis tersebut meliputi 2 jenis rayap tanah ( Nasutitermes Sp dan Odontotermes Sp.) dan 1 jenis rayap subteran ( Coptotermes curvignatus ) dan 7 blok tidak terserang rayap Blok yang paling banyak terserang adalah blok Q karena di blok tersebut banyak terdapat pohon yang mudah rapuh sehingga rayap menyerang pohon diblok tersebut. Rayap yang paling banyak menyerang pohon di Kawasan Arboretum ialah Nasutitermes $S p$. Jenis-jenis rayap yang ditemukan di Kawasan Arboretum disajikan pada Tabel 1.

Tabel 1. Hasil Identifikasi Jenis Rayap (Results of Identification of Termites)

\begin{tabular}{llllll}
\hline No & Blok & Jenis & Nama Ilmiah & Famili & Pohon yang di serang \\
\hline 1 & A1 & Rayap Subteran & Coptotermes curvignatus & Rhinotermitidae & Shorea seminis \\
2 & A2 & Rayap Subteran & Coptotermes curvignatus & Rhinotermitidae & Acacia mangium \\
3 & B1 & Rayap Tanah & Nasutitermes $s p$ & Termitidae & Dillenia \\
4 & B2 & Rayap Tanah & Nasutitermes $s p$ & Termitidae & Acacia mangium \\
5 & C1 & Rayap Tanah & Nasutitermes $s p$ & Termitidae & Shorea seminis \\
6 & E1 & Rayap Tanah & Nasutitermes $s p$ & Termitidae & Acacia mangium \\
7 & E2 & Rayap Tanah & Nasutitermes $s p$ & Termitidae & Acacia mangium \\
8 & F1 & Rayap Tanah & Nasutitermes $s p$ & Termitidae & Paraserianthes falcataria \\
9 & F2 & Rayap Tanah & Nasutitermes $s p$ & Termitidae & Shorea revoluta \\
\hline
\end{tabular}




\begin{tabular}{|c|c|c|c|c|c|}
\hline No & Blok & Jenis & Nama Ilmiah & Famili & Pohon yang di serang \\
\hline 10 & F3 & Rayap Tanah & Nasutitermes $s p$ & Termitidae & Macarangga pruinosa \\
\hline 12 & $\mathrm{~J} 1$ & Rayap Subteran & Coptotermes curvignatus & Rhinotermitidae & Gluta renghas \\
\hline 11 & $\mathrm{H} 1$ & Rayap Tanah & Nasutitermes $s p$ & Termitidae & Paraserianthes falcataria \\
\hline 13 & N1 & Rayap Tanah & Nasutitermes $s p$ & Termitidae & Melicope lunu-acenda \\
\hline 14 & $\mathrm{~N} 2$ & Rayap Tanah & Nasutitermes sp & Termitidae & Acacia auriculiformis \\
\hline 15 & N3 & Rayap Subteran & Coptotermes curvignatus & Rhinotermitidae & Melicope lunu-acenda \\
\hline 16 & N4 & Rayap Subteran & Coptotermes curvignatus & Rhinotermitidae & Melicope lunu-acenda \\
\hline 17 & N5 & Rayap Tanah & Nasutitermes $s p$ & Termitidae & Acacia auriculiformis \\
\hline 18 & $\mathrm{O} 1$ & Rayap Subteran & Coptotermes curvignatus & Rhinotermitidae & Paraserianthes falcataria \\
\hline 19 & P1 & Rayap Subteran & Coptotermes curvignatus & Rhinotermitidae & Shorea pacipila \\
\hline 20 & $\mathrm{P} 2$ & Rayap Subteran & Coptotermes curvignatus & Rhinotermitidae & Shorea $s p$ \\
\hline 21 & P3 & Rayap Tanah & Nasutitermes $s p$ & Termitidae & Shorea pacipila \\
\hline 22 & $\mathrm{P} 4$ & Rayap Tanah & Nasutitermes sp & Termitidae & Acacia mangium \\
\hline 23 & Q1 & Rayap tanah & Nasutitermes $s p$ & Termitidae & Acacia auriculiformis \\
\hline 24 & Q2 & Rayap Tanah & Nasutitermes $s p$ & Termitidae & Melicope lunu-acenda \\
\hline 25 & Q3 & Rayap Tanah & Nasutitermes sp & Termitidae & Acacia mangium \\
\hline 26 & Q4 & Rayap Tanah & Nasutitermes sp & Termitidae & Acacia mangium \\
\hline 27 & Q5 & Rayap Tanah & Odontotermes sp & Termitidae & Acacia auriculiformis \\
\hline 28 & Q6 & Rayap Tanah & Nasutitermes sp & Termitidae & Acacia mangium \\
\hline 29 & Q7 & Rayap Tanah & Nasutitermes $s p$ & Termitidae & Acacia mangium \\
\hline 30 & Q8 & Rayap Tanah & Nasutitermes sp & Termitidae & Acacia mangium \\
\hline 31 & Q9 & Rayap Tanah & Nasutitermes $s p$ & Termitidae & Calophillum inopilum \\
\hline 32 & $\mathrm{R} 1$ & Rayap Tanah & Nasutitermes $s p$ & Termitidae & Acacia mangium \\
\hline 33 & $\mathrm{R} 2$ & Rayap Tanah & Nasutitermes sp & Termitidae & Acacia mangium \\
\hline 34 & R3 & Rayap Tanah & Nasutitermes $s p$ & Termitidae & Acacia auriculiformis \\
\hline 35 & $\mathrm{R} 4$ & Rayap Subteran & Coptotermes curvignatus & Rhinotermitidae & Shorea $s p$ \\
\hline 36 & $\mathrm{~S} 1$ & Rayap Tanah & Nasutitermes $s p$ & Termitidae & Melicope lunu-acenda \\
\hline 37 & $\mathrm{~S} 2$ & Rayap Subteran & Coptotermes curvignatus & Rhinotermitidae & Melicope lunu-acenda \\
\hline 38 & S3 & Rayao Tanah & Nasutitermes $s p$ & Termitiadae & Melicope lubu-acenda \\
\hline 39 & $\mathrm{~S} 4$ & Rayap Tanah & Nasutitermes $s p$ & Termitidae & Acacia mangium \\
\hline 40 & S5 & Rayap Tanah & Nasutitermes $s p$ & Termitidae & Acacia auriculiformis \\
\hline 41 & S6 & Rayap Tanah & Nasutitermes sp & Termitidae & Nephelium lappaceum \\
\hline
\end{tabular}

Jenis rayap yang ditemukan di Arboretum sebanyak 3 jenis yaitu sebagai berikut :

a. Nasutitermes $S p$, di temukan di blok B1, B2, C1, E1, E2, F1, F2, F3, H1, N1, N2, N5, P3, P4, Q1, Q2, Q3, Q4, Q6, Q7, Q8, Q9, R1, R2, R3, S1, S3, S4, S5, dan S6.

b. Coptotermes curvignatus, ditemukan di blok A1, A2, J1, N3, N4, O1, P1, P2, R4, dan S2.

c. Odontotermes $S p$, ditemukan di blok Q5.

Rayap Nasutitermes $s p$ menyerang pohon B1 Dillenia, B2 Acacia mangium, C1 Shorea seminis, E1 Acacia mangium, E2 Acacia mangium, F1 Paraserianthes falcataria, F2 Shorea revoluta, F3 Macarangga pruinosa, H1 Paraserianthes falcataria, N1 Melicope lunu-acenda, N2 Acacia auriculiformis N5 Acacia auriculiformis, P3Shorea pacipila, P4 Acacia mangium, Q1 Acacia auriculiformis, Q2 Melicope lипиacenda, Q3 Acacia mangium, Q4 Acacia mangium, Q6 Acacia mangium, Q7 Acacia mangium, Q8 Acacia mangium, Q9 Calophillun inopilum, R1 Acacia mangium, R2 Acacia mangium, 
R3 Acacia auriculiformis, S1 Melicope lunu-acenda, S3 Melicope lunu-acenda, S4 Acacia mangium, S5 Acacia auriculiformis, S6 Nephelium lappaceum. Sedangkan Rayap Coptotermes curvignatus menyerang pohon A1 Shorea seminis, A2 Acacia mangium, J1 Gluta renghas, N3 Melicope lunu-acenda, N4 Melicope lunu-acenda, O1 Paraserianthes falcataria, P1 Shorea pacipila, P2 Shorea sp, R4 Shorea sp, S2 Melicope lunu-acenda dan Rayap jenis Odontotermes ditemukan di blok Q5 menyerang pohon Acacia auriculiformis.

Klasifikasi dan keterangan setiap jenis rayap diuraikan sebagai berikut :

a. Nasutitermes $S p$.

Nasutitermes $S p$ merupakan rayap tanah (ground-duwweller) yang bersifat arboreal jenis sarang yang dihuninya adalah sarang karton (carton-nest). Sarang ini terbentuk dari campuran tanah serasah kayu, sariva dan cairan feses. Sifat dan konstruksi sarang seperti kertas, rapuh dan mudah patah (Thorne dan Haverti, 2000). Nasuti matangensis ditemukan di wilayah Solok, Solok Selatan dan tanah datar, rayap ini umum dijumpai di dataran tinggi.

Kasta prajurit jenis rayap ini ditandai dengan penonjolan pada bagian depan kepalanya, hal ini merupakan ciri khas dari jenis Nasutitermes sp. Selain itu ciri-ciri umum yang dimiliki oleh jenis ini yaitu kepala bulat bewarna kuning kecoklatan, antena bewarna coklat kekuningan, ruas antena 13-15 ruas, panjang secara keseluruhan kurang lebih 5,3 $\mathrm{mm}$, mandibula bewarna coklat agak gelap, panjang kaki 1,5 mm, jumlah kaki 6 ruas. Kasta prajurit tugasnya mempertahankan kelangsungan hidup koloninya. Mereka berjalan hilir mudik diantara para pekerja yang sibuk mencari dan mengangkut makanan.

Kasta Pekerja tubuh bewarna putih kekuning kuningan sampai kecoklatan, kepala serupa, jumlah antena antara 12 sampai 15 segmen. Kasta pekerja tugasnya ialah membentuk sebagian besar koloni rayap. Tidak kurang dari 80 persen populasi dalam koloni merupakan individu-individu pekerja. Tugasnya melulu hanya bekerja tanpa berhenti hilir mudik di dalam liangliang kembara dalam rangka mencari makanan dan mengangkutnya ke sarang, membuat terowonganterowongan, menyuapi dan membersihkan reproduktif dan prajurit, membersihkan telur-telur, dan membunuh serta memakan rayap-rayap yang tidak produktif lagi. ( Gambar 1 ). 


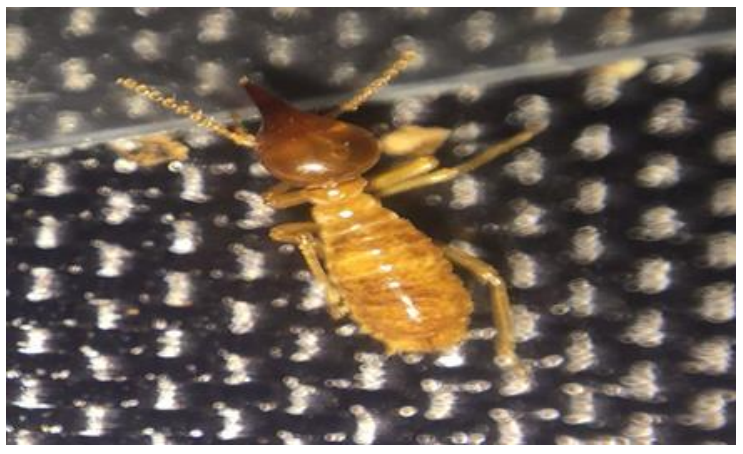

a. Kasta Prajurit (Warrior Caste)

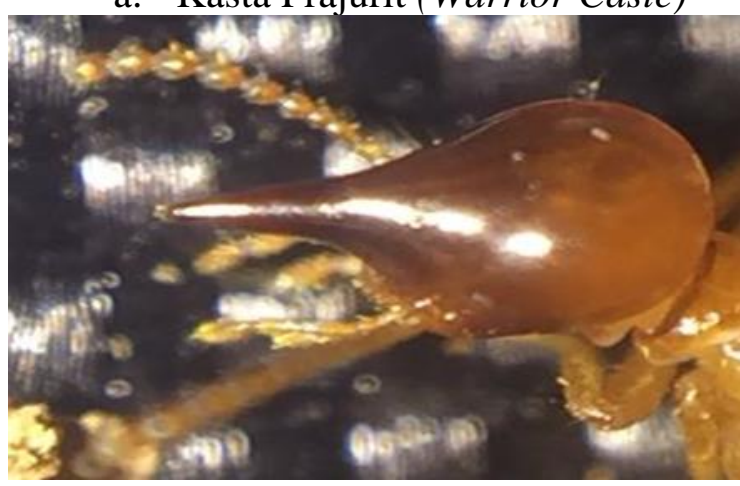

c. Kepala Rayap (Termite Head)

Gambar 1. Rayap Nasutite

\section{b. Coptotermes Curvignatus}

Coptotermes Curvignatus adalah Rayap Subteran umumnya hidup didalam tanah yang mengandung banyak bahan kayu yang telah mati atau membusuk, tungak pohon baik yang telah mati maupun yang masih hidup. Di Indonesia rayap subteran yang paling banyak merusak adalah jenis-jenis dari Famili Rhinotermitidae terutama jenis Coptotermes Curvignatus. Genus Coptotermes Curvignatus dikenal sebagai rayap dengan serangan yang paling ganas, prilaku rayap ini mirip rayap tanah namun perbedaan utama adalah kemampuan untuk bersarang didalam kayu yang diserangnya, walaupun tidak ada hubungan dengan tanah asal saja sarang tersebut

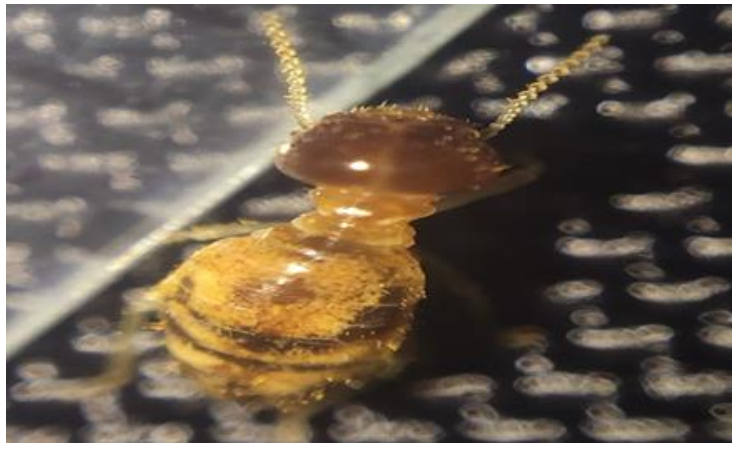

b. Kasta Pekerja (Worker Caste)

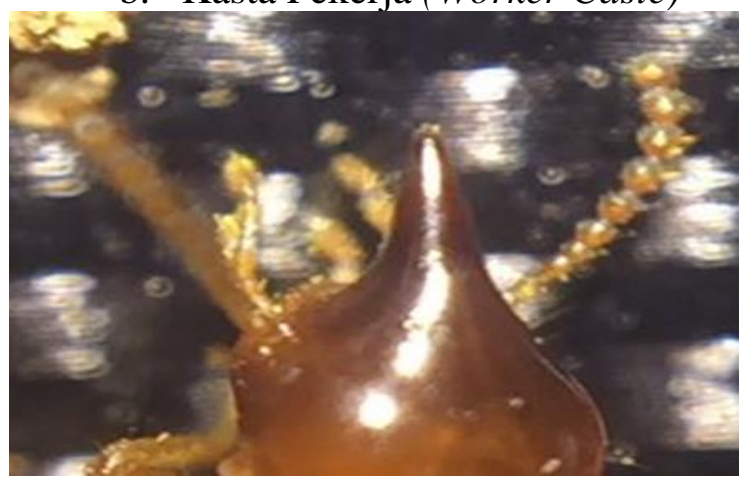

d. Mandibulate

ermes Sp. (Termite Nasutitermes Sp)

memperoleh lembab misalnya dari tetesan air hujan.

Kasta prajurit mempunyai karakter dengan kepala bewarna kuning, antenna, lambrum dan pronotum berwarna kuning pucat. Bentuk kepala bulat memenjang seperti telur. Fontanel sangat jelas terlihat dan biasanya mengeluarkan cairan putih seperti susu yang digunakan untuk pertahanan diri dari musuhnya. Antenna terdiri dari 15 ruas, ruas kedua dan ruas keempat sama panjangnya. Mandibel lurus dan diujungnya sedikit melengkung, batas antara sebelah dalam dari mandibel kanan sama sekali rata. Rata-rata panjang keseluruhan badan prajurit 5,00-7,29 mm. Kasta prajurit tugasnya melindungi koloni terhadap gangguan dari luar. Kasta prajurit dicirikan 
dengan bentuk kepala yang besar dengan sklerotisasi yang kuat. Anggotaanggota kasta ini mempunyai rahang (mandibel) atau rostum yang besar dan kuat sehingga menyulitkannya untuk menjangkau dan menggigit makanannya sendiri.

Kasta pekerja panjang keseluruhan badan 4,56-6,32 $\mathrm{mm}$, lebar kepala

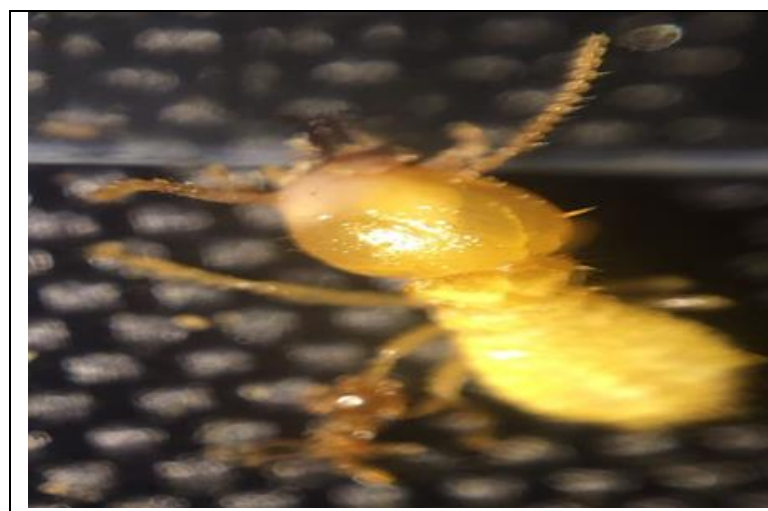

a. Kasta Prajurit (Warrior Caste)

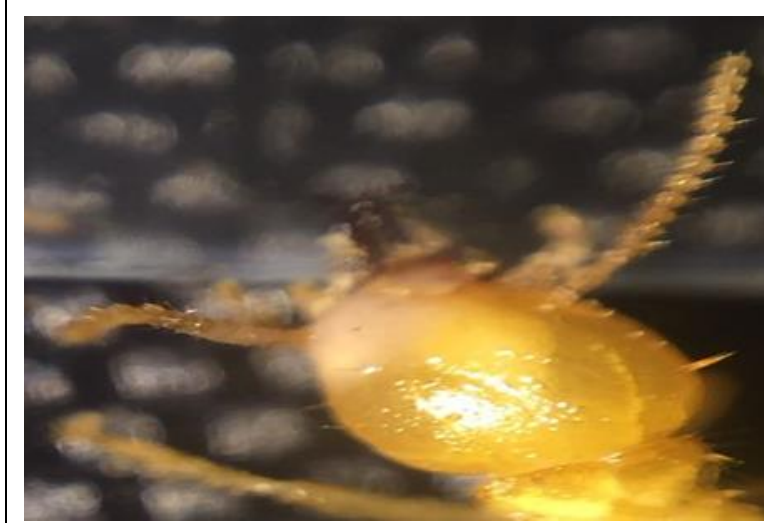

c. Kepala Rayap (Termite Head) pekerja 1,07-1,56 $\mathrm{mm}$, panjang kepala 1,15-1,87 mm. Bagian abdomen ditutupi dengan rambut yang menyerupai duri. Abdomen bewarna putih kekuning-kuningan. Kasta pekerja tugasnya adalah memberi makan anggota-anggota koloni lainnya, merawat telur, serta membuat dan merawat sarang.

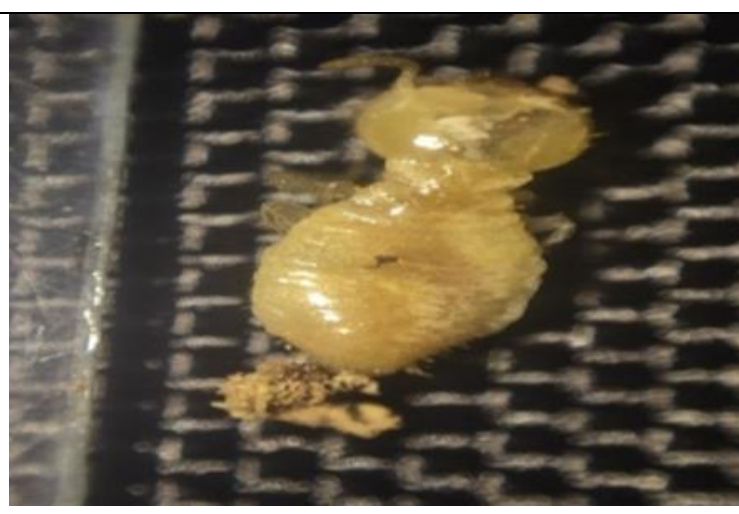

b. Kasta Pekerja (Worker Caste)

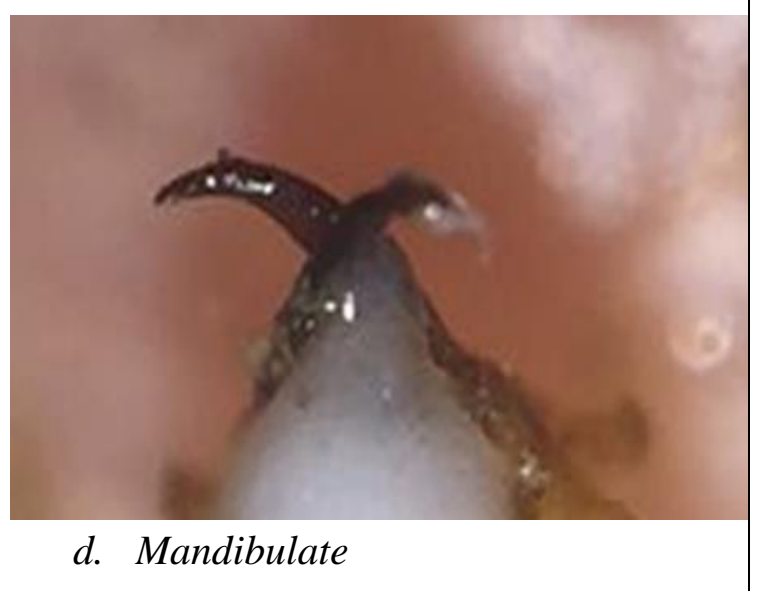

\section{Gambar 2. Rayap Coptotermes Curvignatus (Termite Coptotermes Curvignatus)}

Odontotermes $S p$ adalah jenis rayap tanah dari Famili Termitidae, rayap ini bersarang didalam tanah terutama dekat pada bahan organik yang mengandung selulosa seperti kayu dan serasah. Rayap ini biasanya juga menyerang bangunan. Jenis rayap ini sangat ganas dapat menyerang obyek-obyek bejarak sampai 200 meter dari sarangnya. Untuk mencapai kayu sasaranya rayap ini bahkan dapat menembus tembok beberapa $\mathrm{cm}$ dengan bantuan enzim yang dikeluarkanya. Menurut Hasan (1984 ) Rayap odontotermes Sp adalah rayap pembersih sampah yang sering memakan kayu maupun kulit kayu yang sudah mati atau membusuk. Penyerangan terhadap jaringan ini akan 
menghalangi penyembuhan luka-luka dan menyebabkan lubang-lubang di dalam batang.

Kasta prajurit rayap ini ialah mandibula tebal, antena 15-19 ruas, kepala agak besar dan melebar,panjang keseluruhan 6,7 mm, warna kuning agak kecoklatan. Kasta prajurit tugasnya mempertahankan kelangsungan hidup koloninya. Mereka berjalan hilir mudik diantara para pekerja yang sibuk mencari dan mengangkut makanan. Setiap ada

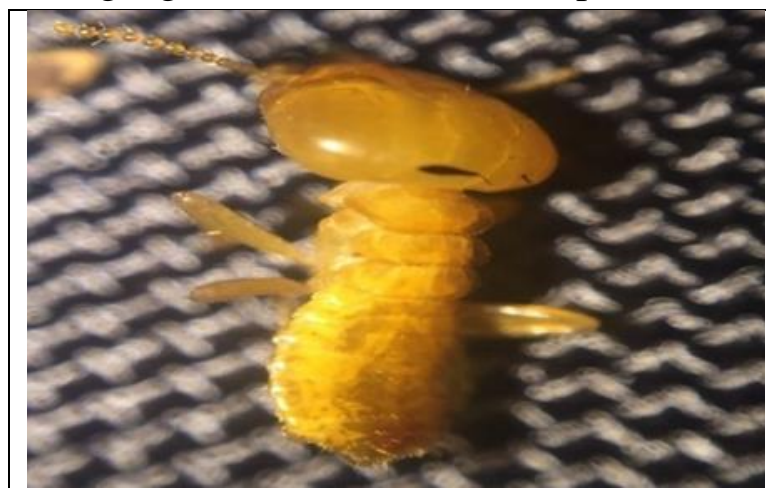

a. Kasta Prajurit (Warrior Caste)

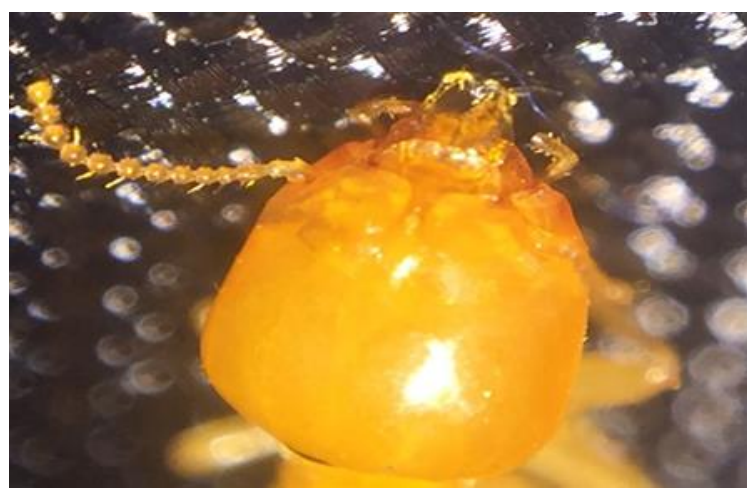

c. Kepala Rayap (Termite Head) gangguan dapat diteruskan melalui "suara" tertentu sehingga prajuritprajurit bergegas menuju ke sumber gangguan dan berusaha mengatasinya.

Kasta pekerja dengan ciri-ciri kepala bulat warna putih kekuningan, Badan bulat lebar agak memanjang warna putih kekuningan. Ruas antena 13-15 ruas. Panjang keseluruhan 0,8 $\mathrm{mm}$. Kasta pekerja tugasnya ialah membentuk sebagian besar koloni rayap.

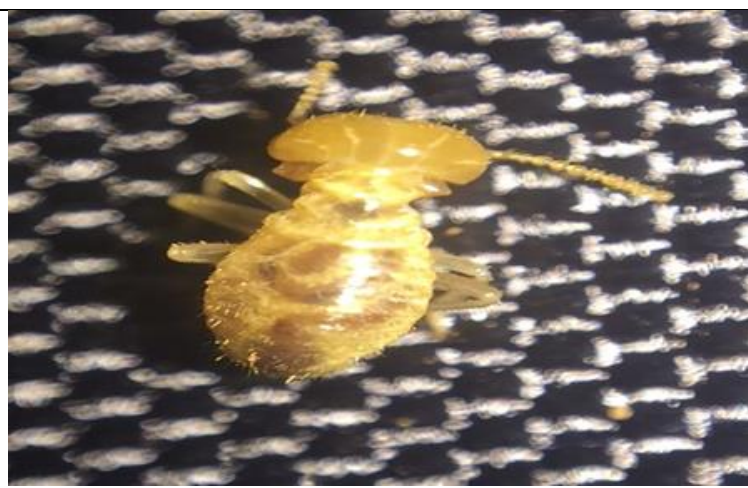

b. Kasta Pekerja (Worker Caste)

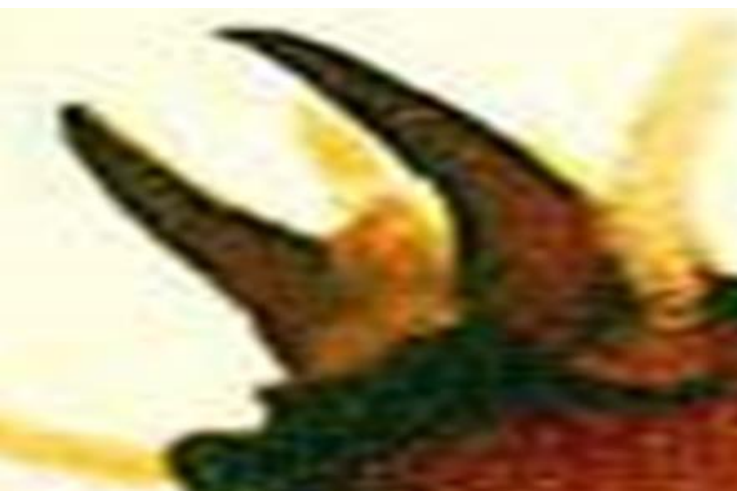

d. Mandibulate

Gambar 3. Rayap Odontotermes Sp.(Termite Odontotermes Sp.) 


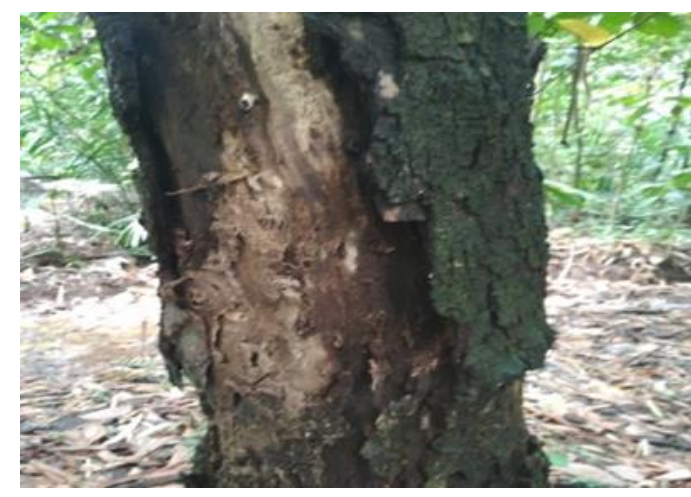

a. Acacia mangium

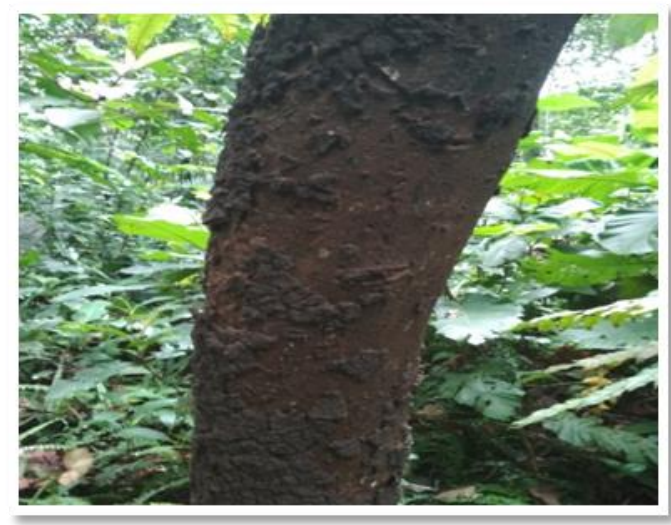

c. Melicopelunu-acenda

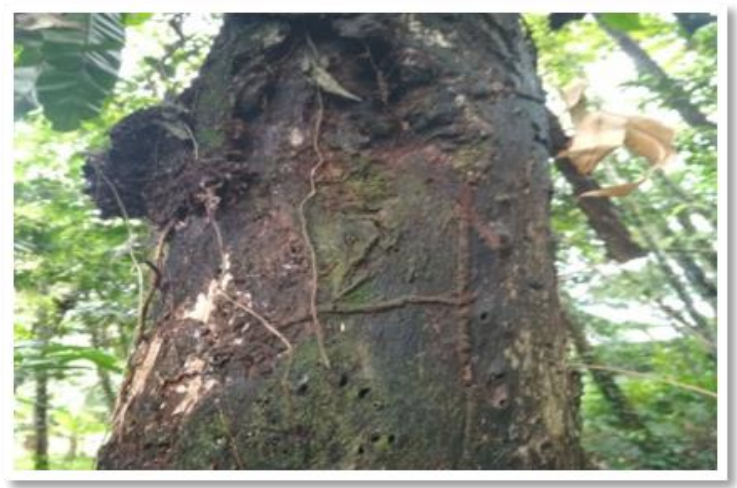

b. Acacia Auriculiformis

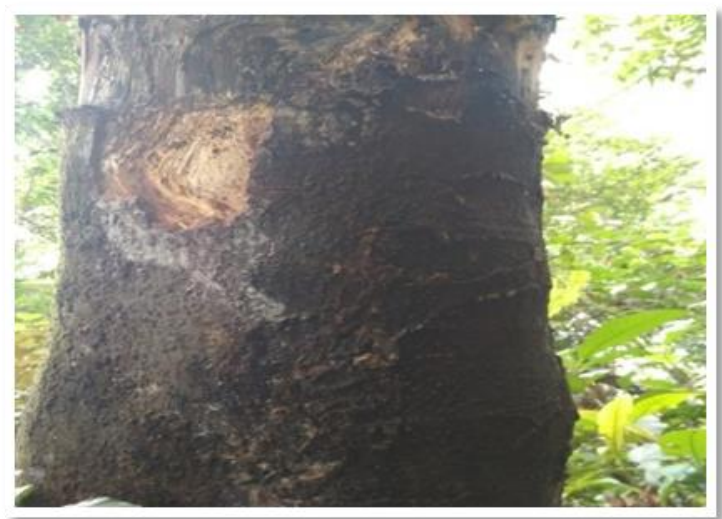

d. Paraserianthes falcataria

Gambar 4. Jenis Pohon yang Diserang Rayap Di Kawasan Arboretum Sylva Untan (Tree species that are attacked by termites in the Arboretum Sylva Untan)

Berdasarkan pengamatan di Kawasan Arboretum Sylva Untan pohon yang paling banyak diserang rayap ialah :

a. Acacia mangium blok A2, B2, E1, ,E2, P4, Q3，Q4，Q6, Q7, Q8, R1, $\mathrm{R} 2$, dan S4.

b. Acacia Auriculiformis blok N2, N5, Q1, Q5, R3, dan S5.

c. Melicope lunu-acenda blok N1, N3, N4, Q2, S1, S2, dan S3.

d. Paraserianthes falcataria blok F1, H1, dan O1.

Jenis pohon Acacia mangium yang diserang 13 pohon, Acacia auriculiformis 6 pohon, Melicope lunu- acenda 7 pohon, dan Paraserianthes falcataria 3 pohon.

Kesimpulan

Berdasarkan Rayap yang menyerang Areal Arboretum ada 3 Jenis Rayap yaitu :

1. 2 jenis rayap tanah (Nasutitermes $\mathrm{Sp}$, Odontotermes $\mathrm{Sp}$ ) dan rayap Subteran (Coptotermes curvignatus).

2. Pohon - pohon yang diserang di Areal Arboretum terdapat 13 jenis meliputi : Acacia mangium, Acacia auriculiformis, Melicope lunuacenda, Paraserianthes falcataria, Shorea seminis, Shorea pacipila, Shorea sp, Shorea revoluta, Dillenia 
sp, Gluta renghas, Calophillum inopilum, Nephelium lappaceum, Macarangga pruinose.

3. Pohon yang paling banyak terkena serangan ialah Acacia mangium dan Acacia Auriculiformis.

Saran

Pohon yang rusak akibat serangan rayap perlu ditangani dengan melakukan pengendalian rayap.

DAFTAR PUSTAKA

Astute, 2013. Identifikasi, Sebaran Derajat Kerusakan Kayu oleh Serangan Rayap Coptotermes (Isoptera: Rhinotermitidae) Sulawesi Selatan. Universitas Hasnuddin Makassar.
Nandika D, Rismayadi Y, Diba F. 2003. Biologi Rayap dan Pengendaliannya. Muhammadiyah University Press, Surakarta.

Prasetiyo KW Dan Yusuf S. 2005. Mencegah dan Membasmi Rayap Secara Ramah Lingkungan dan Kimiawi, Agro Media Pustaka, Depok. $63 \mathrm{~h}$.

Tim Riset Arboretum 2013, Peta Kawasan Arboretum, Sylva Indonesia PC. Universitas Tanjungpura Fakultas Kehutanan. 